University of Nebraska - Lincoln

DigitalCommons@University of Nebraska - Lincoln

Publications from USDA-ARS / UNL Faculty

U.S. Department of Agriculture: Agricultural

Research Service, Lincoln, Nebraska

2004

Registration of Nineteen Waxy Spring Wheats

Robert A. Graybosch

USDA-ARS; University of Nebraska-Lincoln, bob.graybosch@ars.usda.gov

E.J. Souza

University of Idaho

W.A. Berzonsky

North Dakota State University

P. Stephen Baenziger

University of Nebraska-Lincoln, pbaenziger1@unl.edu

D.J. McVey

USDA-ARS

See next page for additional authors

Follow this and additional works at: https://digitalcommons.unl.edu/usdaarsfacpub

Part of the Agricultural Science Commons

Graybosch, Robert A.; Souza, E.J.; Berzonsky, W.A.; Baenziger, P. Stephen; McVey, D.J.; and Chung, O.K., "Registration of Nineteen Waxy Spring Wheats" (2004). Publications from USDA-ARS / UNL Faculty. 907. https://digitalcommons.unl.edu/usdaarsfacpub/907

This Article is brought to you for free and open access by the U.S. Department of Agriculture: Agricultural Research Service, Lincoln, Nebraska at DigitalCommons@University of Nebraska - Lincoln. It has been accepted for inclusion in Publications from USDA-ARS / UNL Faculty by an authorized administrator of DigitalCommons@University of Nebraska - Lincoln. 
Authors

Robert A. Graybosch, E.J. Souza, W.A. Berzonsky, P. Stephen Baenziger, D.J. McVey, and O.K. Chung 


\section{Registration of Nineteen Waxy Spring Wheats}

Nineteen spring waxy (amylose-free) wheat (Triticum aestivum L.) germplasm lines (Reg. no. GP-748 to GP-766, PI 619354-619357, 619359-619363, 619365-619369, 619371-619375) were developed and released by the ARS, USDA, and the Nebraska Agricultural Experiment Station in cooperation with the Agricultural Experiment Stations of North Dakota and Idaho in September 2002. Waxy wheats carry three nonfunctional (null) alleles $(W x-A 1 b, W x-B 1 b$, and $W x-D 1 b)$ at the genetic loci encoding the enzyme granule-bound starch synthase (GBSS, EC 2.4.1.21) (Nakamura et al., 1995). GBSS also is known as the "waxy" protein. Waxy wheats produce endosperm starch that is nearly devoid of amylose. Such starch confers unique functional properties to derived wheat flour. Suggested uses for waxy wheats include the production of modified food starches, a blending agent to create flours with optimal amylose concentration for the production of a variety of sheeted and baked food products, and as an animal feed (reviewed by Graybosch, 1998). Waxy wheats also are useful as donors of the $W x$ null alleles, which may be used to develop partial waxy or reduced-amylose wheats. The presence of one or two such alleles can result in wheat flours with superior performance in certain food applications including white salted noodles (Epstein et al., 2002). Few waxy wheats have been publicly available to date, and those released (Morris and Konzak, 2001) are ill-adapted to North American spring wheat production zones. The release of this set of 19 waxy lines greatly expands the number of available genetic backgrounds carrying the waxy trait in wheat. Pedigrees and Plant Introduction (PI) numbers of the lines are listed in Table 1.

Lines were developed from matings between Asian and North American sources of the $W x$ null alleles. After the last cross in each pedigree, the brush end of $F_{2}$ plants was stained with a dilute solution of $\mathrm{I}_{2} \mathrm{KI}$ and the germ end was saved for planting. Under these staining conditions, waxy seed were identified by their red-brown color, as opposed to the dark purple-black color typical of wild-type or partial waxy lines (Nakamura et al., 1995). $F_{2}$ plants were grown, without vernalization, in greenhouses in the fall of 1998, and maintained and harvested individually. Only true spring growth habit types (e.g., those that flowered and set seed under nonvernalizing conditions) were harvested. $\mathrm{F}_{2}$-derived $\mathrm{F}_{3}$ single-plant progeny rows were grown at Aberdeen, ID, USA in the spring of 1999. At harvest the $19 \mathrm{~F}_{2: 4}$ waxy lines were selected from these progeny rows, on the basis of uniformity of phenotype under field conditions and uniformity of the waxy trait.

Grain yields of the 19 waxy lines, based on replicated tests in three locations (Fargo, ND and Aberdeen, ID, 2000; Mead, NE, 2001), are given in Table 2. Grain yields ranged from a high of $3606 \mathrm{~kg} / \mathrm{ha}$ in PI 619362 to a low of $2076 \mathrm{~kg} / \mathrm{ha}$ in PI 619360. In the same testing environments, the spring wheat cultivars 'Express' (PI 573003), 'Westbred 926' and 'Klasic' (PI 486139) averaged 3441, 3703, and $2799 \mathrm{~kg} / \mathrm{ha}$, respectively. On the basis of assessment by a Perten Single Kernel Hardness Characterization System, mean hardness scores (Table 2) identified three soft endosperm textured wheats, while the remaining 16 waxy wheats were classified as hard wheats. Fifteen of the lines breed true for red grain color, while four are heterogeneous for red and white grain (Table 2).

Table 2 also lists postulated resistance genes to foliar diseases. On the basis of reactions to current races of leaf rust 
Table 1. Plant Introduction (PI) numbers, experimental line designations, and pedigrees of 19 spring waxy wheats.

\begin{tabular}{|c|c|c|}
\hline PI no. & Experimental line designation & Pedigree \\
\hline 619354 & 99ID388 & Kanto107/MN2540/3/BaiHuo5/K94H115//IDO469 \\
\hline 619355 & 99ID389 & Kanto107/MN2540/3/BaiHuo5/K94H115//IDO469 \\
\hline 619356 & 99ID435 & BaiHuo/L910097//Kanto107/3/Kanto107/Yanshi9 \\
\hline 619357 & 99ID450 & BaiHuo3/Cimarron//MN91227/3/Kanto107 \\
\hline 619359 & 99ID477 & BaiHuo/Chris//Kanto107 \\
\hline 619360 & 99ID484 & BaiHuo/L910097//Kanto107/3/BaiHuo3/Cimarron//MN91227 \\
\hline 619361 & 99ID490 & BaiHuo/Kanto107//Express \\
\hline 619362 & 99ID496 & BaiHuo/Kanto107//Express \\
\hline 619363 & 99ID498 & BaiHuo/Kanto107//Express \\
\hline 619365 & $99 I D 516$ & KY87C-42-8-5/Collin//ACMajestic/3/Kanto107/BaiHuo \\
\hline 619366 & $99 I D 520$ & KY87C-42-8-5/Collin//ACMajestic/3/Kanto107/BaiHuo \\
\hline 619367 & $99 I D 524$ & KY87C-42-8-5/Collin//ACMajestic/3/Kanto107/BaiHuo \\
\hline 619368 & $991 D 529$ & KY87C-42-8-5/Collin//ACMajestic/3/Kanto107/BaiHuo \\
\hline 619369 & $99 I D 536$ & KY87C-42-8-5/Collin//ACMajestic/3/Kanto107/BaiHuo \\
\hline 619371 & $99 I D 548$ & Penawawa/NE92608//BaiHuo/3/BaiHuo4/Kanto107/A92-3327/Kanto107 \\
\hline 619372 & $99 I D 554$ & Kanto107/BaiHuo//BaiHuo/Russ \\
\hline 619373 & 99ID569 & BaiHuo/Kanto107I/ACMajestic \\
\hline 619374 & 99ID590 & BaiHuo/ACMajestic//Kanto107/MN2540 \\
\hline 619375 & $99 I D 594$ & BaiHuo/Gunnar//Kanto107/Penawawa \\
\hline
\end{tabular}

Table 2. Mean grain yield, grain hardness class, and grain color characteristics of 19 waxy spring wheats.

\begin{tabular}{|c|c|c|c|c|c|}
\hline \multirow[b]{2}{*}{ Line } & \multirow[b]{2}{*}{ Grain yield } & \multirow[b]{2}{*}{ Grain hardness class } & \multirow[b]{2}{*}{ Grain color } & \multicolumn{2}{|c|}{ Postulated resistance genes $\dagger$} \\
\hline & & & & leaf rust & stem rust \\
\hline & kg/ha & & & & \\
\hline 619354 & 2257 & hard & red & + & none \\
\hline 619355 & 2984 & hard & red & none & none \\
\hline 619356 & 2660 & hard & red & $14 \mathrm{a},+$ & 10 or 17 \\
\hline 619357 & 2352 & soft & red & + & none \\
\hline 619359 & 2611 & hard & red & $16,+$ & none \\
\hline 619360 & 2076 & hard & red & none & none \\
\hline 619361 & 3228 & soft & red/white & $\mathbf{1},+$ & none \\
\hline 619362 & 3606 & hard & red & + & none \\
\hline 619363 & 2828 & hard & red & none & none \\
\hline 619365 & 2829 & hard & red & $9,+$ & 10 or 17 \\
\hline 619366 & 3104 & hard & red/white & + & 36 \\
\hline 619367 & 2633 & hard & red/white & + & 10 or 17 \\
\hline 619368 & 3443 & hard & red/white & $9,+$ & 10 or 17 \\
\hline 619369 & 2955 & hard & red & + & none \\
\hline 619371 & 2960 & hard & red & none & none \\
\hline 619372 & 2588 & hard & red & $16,+$ & none \\
\hline 619373 & 2682 & hard & red & + & none \\
\hline 619374 & 2897 & hard & red & + & 10 or 17 \\
\hline 619375 & 3299 & soft & red & + & none \\
\hline
\end{tabular}

$\dagger+$ designates presence of unknown gene postulated.

(caused by Puccinia recondita Roberge ex Desmaz.), the following resistance genes are postulated as being present in the respective waxy lines: Lr1, PI 619361; Lr16, PI 619372, PI 619359; Lr14a, PI 619356; Lr9. PI 619368, PI 619365. Unidentified additional leaf rust resistance genes are speculated to occur in all lines with the exception of PI 619363, PI 619360, PI 619371, and PI 619355. These last four lines are susceptible to current leaf rust races. Resistance genes to current races of stem rust (caused by Puccinia graminis Pers.: Pers.) occur in PI 619356, PI 619367, PI 619388, PI 619374, and PI 619365 (SR10 or Sr17). Resistance gene Sr36 was found in PI 619366. The remaining lines are susceptible to current races of stem rust.

Seed of all lines has been deposited in the USDA National Small Grains Collection, Aberdeen, ID. Small quantities of seed may be obtained from R. Graybosch, USDA-ARS, University of Nebraska, Lincoln, NE 68583. It is requested that the source of this material be acknowledged in future usage by wheat breeding and genetics programs.

R.A. Graybosch, * E.J. Souza, W.A. Berzonsky,
P.S. Baenziger, D.J. McVey, and O.K. Chung References

Epstein, J., C.F. Morris, and K.C. Huber. 2002. Instrumental texture of white salted noodles prepared from recombinant inbred lines of wheat differing in the three granule bound starch synthase (Waxy) genes. J. Cereal Sci. 35:39-50.

Graybosch, R.A. 1998. Waxy wheats: Origin, properties and prospects. Trends Food Sci. Technol. 9:135-142.

Morris, C.F., and C.F. Konzak. 2001. Registration of hard and soft homozygous waxy wheat germplasm. Crop Sci. 41:934-935.

Nakamura, T., M. Yamamori, H. Hirano, S. Hidaka, and T. Nagamine. 1995. Production of waxy (amylose-free) wheats. Mol. Gen. Genet. 248:253-259.

R.A. Graybosch, USDA-ARS, 344 Keim, University of Nebraska, Lincoln, NE, 68583; E.J. Souza, University of Idaho, Aberdeen, ID; W.A. Berzonsky, North Dakota State University, Fargo, ND; P.S. Baenziger, University of Nebraska, Lincoln, NE; D.J. McVey, USDA-ARS, St. Paul, MN; O.K. Chung, USDA-ARS, Manhattan, KS. Joint contribution of the United States Department of Agriculture, Agriculture Research Service and the University of Nebraska Agriculture Research Division as Journal Series Paper No. 13913. Registration by CSSA. Accepted 31 Dec. 2003. *Corresponding author (rag@unlserve.unl.edu).

Published in Crop Sci. 44:1491-1492 (2004). 